\title{
Acolpenteron australe sp. n. (Dactylogyridae: Dactylogyrinae), a new species from the ureters of Percichthys trucha (Perciformes: Percichthyidae) in Patagonia (Argentina)
}

\author{
Gustavo P. Viozzi and Norma L. Brugni \\ Laboratorio de Parasitología, Centro Regional Universitario Bariloche, Universidad Nacional del Comahue, Quintral 1250 , \\ (8400) Bariloche, Río Negro, Argentina
}

Key words: Acolpenteron australe, Monogenea, Percichthys trucha, Patagonia

\begin{abstract}
Acolpenteron australe sp. n. (Dactylogyridae, Dactylogyrinae) is described from ureters and renal tubules of Percichthys trucha (Cuvier et Valenciennes) (Perciformes, Percichthyidae) from Andean Patagonian lakes. The new species has a haptor with 14 hooks, with shanks comprised of two subunits. It has overlapped intercaecal gonads, male copulatory organ as a sclerotized tube with one counterclockwise coil and a J-shaped accessory piece. It differs from the other species of Acolpenteron by having a non-forked accessory piece. This is the first monogenean species described from a percichthyid host in South America.
\end{abstract}

Eight monogenean species have been described from the urinary systems of teleostean fishes: Urogyrus cichlidarum Bilong Bilong, Birgi et Euzet, 1994 from Cameroon; Kritskyia moraveci Kohn, 1990, K. annakohnae Boeger, Tanaka et Pavanelli, 2001 and $K$. boegeri Takemoto, Lizama et Pavanelli, 2002 from Brazil; Philureter trigoniopsis Viozzi et Gutiérrez, 2001 from Argentina; Acolpenteron ureteroecetes Fischthal et Allison, 1940 and $A$. catostomi Fischthal et Allison, 1942 from North America and A. nephriticum Gvozdev, 1945 from Russia (Fischthal and Allison 1940, 1941, 1942, Yamaguti 1963, Kohn 1990, Bilong Bilong et al. 1994, Boeger et al. 2001, Viozzi and Gutiérrez 2001, Takemoto et al. 2002). Two species of Pseudacolpenteron Bychowsky et Gussev, 1955 have been described from gills and fins of cyprinid fishes: $P$. pavlovskii Bychowsky et Gussev, 1955 and P. ignotum Gussev, 1955 (Yamaguti 1963, Rogers 1968). Although Yamaguti (1963) synonymized Pseudacolpenteron with Acolpenteron, Rogers (1968) considered Pseudacolpenteron a valid genus due to differences in the eyes, head organs and the site of infection. Kritsky et al. (1978) considered those characters not different enough to separate the genera.

Species of Acolpenteron from ureters have been described from species of Perciformes and Cypriniformes in the North Hemisphere: A. nephriticum from balitorid fishes, A. catostomi parasitizing catostomids and $A$. ureteroecetes centrarchids. Species of the genus have not been described in the South Hemisphere, although $A$. ureteroecetes has been found in different countries due to the introduction of centrarchid fishes (Du Plessis 1948, Hoffman 1970, Bunkley-Williams and Williams 1995). In the present study, a new species from the ureters and renal tubules of Percichthys trucha
(Cuvier et Valenciennes) from Patagonian lakes is described.

\section{MATERIALS AND METHODS}

Specimens of Percichthys trucha from three northwestern Patagonian glacial lakes (Argentina) were collected with aid of gill nets, and then transported to the laboratory and examined. The fish were dissected and parasites removed from ureters with the aid of a dissecting microscope. Monogenean specimens were relaxed in tap water, killed in 1:4,000 formalin and preserved in 5\% formalin. Specimens were stained in Gomori's trichrome and mounted in Canada balsam. Illustrations were prepared with the aid of camera lucida; measurements of male copulatory organ length and the accessory piece were obtained by using a curvimeter on camera lucida drawings. Measurements are expressed in micrometres, averages are followed by the range and number of specimens measured (n) in parentheses.

\section{RESULTS}

Acolpenteron australe sp. $\mathrm{n}$.

Fig. 1

Description: Body elongate, 767 (586-998; $\mathrm{n}=30$ ) long; greatest width $140(106-202 ; \mathrm{n}=30)$ near midlength. Sensory hairs absent. Cephalic lobes and two head organs present. Cephalic glands lateral to pharynx; divided in two pre- postpharyngeal groups. Anterior pair of eyes closer together, posterior pair larger. Pharynx spherical in ventral view, $43(34-53, \mathrm{n}=30)$ in diameter. Oesophagus short. Caeca lacking diverticula, confluent posterior to testis. Peduncle distinguishable from trunk. Haptor $58(46-79, \mathrm{n}=28)$ long, 108 (94$127, \mathrm{n}=26$ ) wide, cup-like ventral extension of peduncle. Hooks similar; each $26(23-28, \mathrm{n}=32)$ long, ventrally orientated, with short broad thumb, delicate 
A

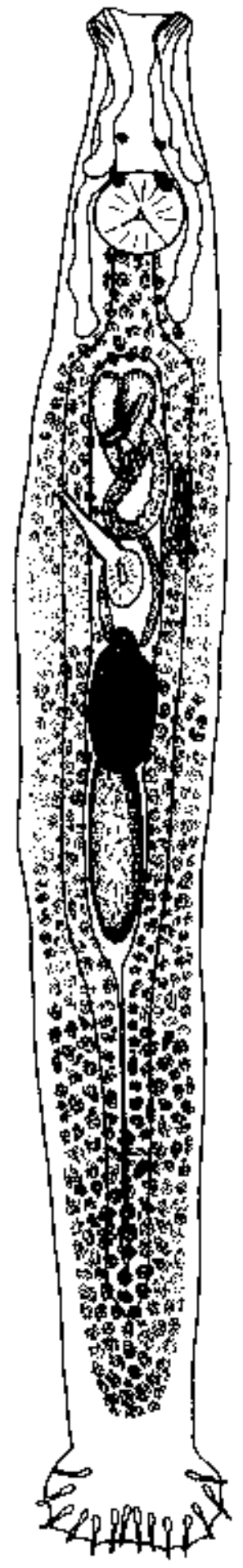

$\mathbf{B}$

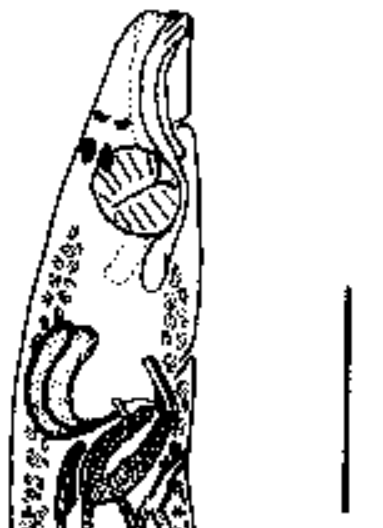

$\mathbf{E}$

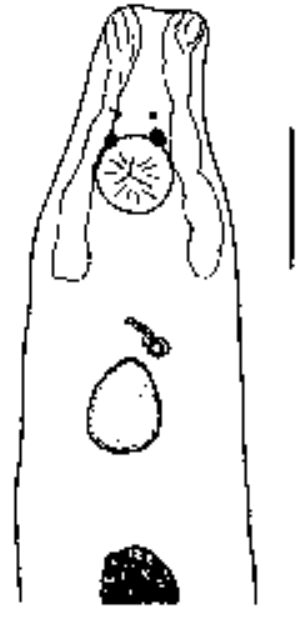

$\mathbf{F}$

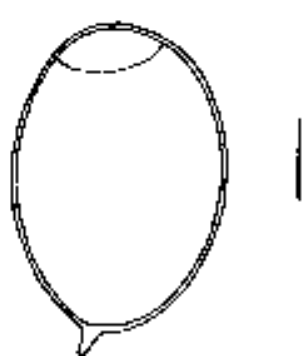

Fig. 1. Acolpenteron australe sp. n. A - whole mount adult (composite, ventral view); $\mathbf{B}$ - whole mount adult (partial lateral view); C - hook (lateral view); D - male copulatory organ (ventral view); $\mathbf{E}$ - anterior part of paratype with egg (dorsal view); $\mathbf{F}-$ egg. Scale bars: A, B, $\mathrm{E}=100 \mu \mathrm{m} ; \mathrm{C}, \mathrm{D}, \mathrm{F}=20 \mu \mathrm{m}$. 
point, shank comprised of two subunits; proximal subunit expanded. FH loop as long as distal subunit of shank. 4A hooks not observed. Male copulatory organ one counterclockwise coil, $63(55-73, \mathrm{n}=12)$ long. Accessory piece J-shaped, $54(50-59, \mathrm{n}=22)$ long. Gonads partially overlapping. Testis $111(72-161, \mathrm{n}=$ 27) long, 55 (24-98, $\mathrm{n}=30$ ) wide, dorsal to ovary. Two prostatic reservoirs dorsal to male copulatory organ. Seminal vesicle elongate vertically at left of male copulatory organ. Germarium ovate, $73(53-96, \mathrm{n}=23)$ long, $41(29-60, n=24)$ wide. Oviduct elongate. Uterus thick-walled. Genital pore midventral in anterior trunk. Vagina tube sclerotized, $37(35-38, n=4)$ long, opening ventrally near right margin of body. Seminal receptacle ventral to oviduct. Vitellaria dense, coextensive with gut. Single large, oval, brownish egg $75(74-76, \mathrm{n}=5)$ long, $56(54-58, \mathrm{n}=5)$ wide, operculate with short polar filament.

T y p e hos t: Percichthys trucha (Cuvier et Valenciennes).

T y p e 1 o c a 1 i t y : Lake Escondido $\left(41^{\circ} 05^{\prime} \mathrm{S}, 71^{\circ} 35^{\prime} \mathrm{W}\right)$, Patagonia, Argentina.

O the r 1 o c a 1 it i e s: Lake Moreno $\left(41^{\circ} 04^{\prime} \mathrm{S}, 71^{\circ} 33^{\prime} \mathrm{W}\right)$, Lake Aluminé ( $\left.38^{\circ} 55^{\prime} \mathrm{S}, 71^{\circ} 10^{\prime} \mathrm{W}\right)$, Patagonia, Argentina.

Site of infection: Ureters, renal tubules.

P r e v a 1 e n c e : 76\% (October 1997, Lake Escondido, $n=$ 17).

Me a n in te n s ity : 6.5 (October 1997, Lake Escondido, $\mathrm{n}=17)$.

M a x i m u m in ten s it y : 117 (May 1999, Lake Moreno).

$\mathrm{S}$ p e c i m e n s d e p o s i t e d : Holotype No. 420/1, five paratypes Nos. 420/2-6 deposited in the Colección Nacional de Parasitología del Museo Argentino de Ciencias Naturales Bernardino Rivadavia, Buenos Aires, Argentina; 6 paratypes Nos. 5097 and 5098 deposited in the Colección Helmintológica del Museo de La Plata, Museo de La Plata, Argentina; 17 paratypes Nos. 162/1-10 and 163/1-7 deposited in the Colección Parasitológica de la Universidad Nacional del Comahue, (Bariloche, Argentina) and two paratypes No. M-379 deposited in the helminthological collection, Institute of Parasitology, Academy of Sciences of the Czech Republic, České Budějovice.

E t y m o 1 o g y : The specific name refers to the latitude of the distribution range of the host species; from Latin australis: southern.

\section{DISCUSSION}

The new species can be designated with Acolpenteron by virtue of the site of infection, the lack of anchors and bars, the presence of 14 ventral marginal hooks, two pre- postpharyngeal cephalic glands, a copulatory complex as a sclerotized tube with a counterclockwise coil, a sclerotized vagina opening ventrally near the right margin of the body, and intestinal caeca lacking diverticula and united posteriorly. Although Kritsky et al. (1978) observed 4A hooks in the haptor of A. catostomi and Pseudacolpenteron pavlovskii, that type of hooks was not observed in the haptor of $A$. australe.

Acolpenteron australe can be differentiated from all other Acolpenteron species by having a non-forked accessory piece. It also differs from $A$. nephriticum by having a distinguishable haptor, overlapping gonads and the shank divided into two subunits. It differs from $A$. ureteroecetes by the straight vaginal tube and from $A$. catostomi by having a unspined male copulatory organ base, a larger distance between testis and the confluence of the intestinal caeca, and by a smaller egg. Additionally, A. australe differs from both, A. ureteroecetes and $A$. catostomi, by lacking sensory hairs. Although $A$. australe was not observed in the urinary bladder, it parasitizes ureters and renal tubules like A. ureteroecetes (Fischthal and Allison 1941, Petrie-Hanson 2001).

The maximum intensity observed in nature was higher in A. australe than in A. ureteroecetes (compare Fischthal and Allison 1941), although pathological signs were not observed. The culture conditions in hatcheries can lead to mortality due to extremely high infections. Mortality and degenerative renal changes due to the heavy infections with $A$. ureteroecetes in cultured Micropterus salmoides were reported in South Africa and USA (Du Plessis 1948, Petrie-Hanson 2001).

Acolpenteron australe is the first species of the genus Acolpenteron described from the South Hemisphere.

Acknowledgements. This study was supported by grant from CONICET, Argentina, and funds provided by UNC 092 and PICT FONCYT 01-00002-00067-A.

\section{REFERENCES}

BILONG BILONG C.F., BIRGI E., EUZET L. 1994: Urogyrus cichlidarum gen. nov., sp. nov., Urogyridae fam. nov., monogène parasite de la vessie urinaire de poissons cichlidés au Cameroun. Can. J. Zool. 72: 561-566.

BOEGER W.A., TANAKA L.K., PAVANELLI G.C. 2001: Neotropical Monogenoidea. 39: a new species of Kritskyia (Dactylogyridae, Ancyrocephalinae) from the ureters and urinary bladder of Serrasalmus marginatus and $S$. spilopleura (Characiformes, Serrasalmidae) from southern Brazil with an emended generic diagnosis. Zoosystema 23: 5-10.
BUNKLEY-WILLIAMS L., WILLIAMS E.H. 1995: Parásitos de Peces de Valor Recreativo en Agua Dulce de Puerto Rico. Departamento de Recursos Naturales y Ambientales de Puerto Rico y Departamento de Ciencias Marinas de la Universidad de Puerto Rico, Mayagüez, 190 pp.

DU PLESSIS S. 1948: A gyrodactyloid parasite from the ureters of largemouth bass at the Jonkershoek Inland Fish Hatchery, South Africa. Trans. Am. Fish. Soc. 75: 105109. 
FISCHTHAL J.H., ALLISON L.N. 1940: Acolpenteron ureteroecetes $\mathrm{n}$. g., n. sp., a monogenetic trematode from the ureters of black basses. J. Parasitol. 26: 34-35.

FISCHTHAL J.H., ALLISON L.N. 1941: Acolpenteron ureteroecetes Fischthal and Allison, 1940, a monogenetic trematode from the ureters of the black basses, with a revision of the family Calceostomatidae (Gyrodactyloidea). J. Parasitol. 27: 517-523.

FISCHTHAL J.H., ALLISON L.N. 1942: Acolpenteron catostomi n. sp. (Gyrodactyloidea: Calceostomatidae), a monogenetic trematode from the ureters of suckers, with observation on its life history and that of $A$. ureteroecetes. Trans. Am. Microsc. Soc. 61: 53-56.

HOFFMAN G.L. 1970: Parasites of North American Freshwater Fishes. University of California Press, Los Angeles, 485 pp.

KOHN A. 1990: Kritskyia moraveci n. g., n. sp. (Monogenea: Dactylogyridae) from the urinary bladder and ureters of Rhamdia quelen (Quoy and Gaimard, 1824) (Pisces: Pimelodidae) in Brazil. Syst. Parasitol. 17: 81-85.

KRITSKY D.C., MIZELLE J.D., BILQEES F.M. 1978: Studies on Monogenea of Pakistan. III. Status of the Calceostomatidae (Parona and Perugia, 1890) with a redescription of Neocalceostoma elongatum (Tripathi, 1957) and the proposal of Neocalceostomoides gen. $\mathrm{n}$. Proc. Helminthol. Soc. Wash. 45: 149-154.
KRITSKY D.C., VanEVERY L.R., BOEGER W.A. 1996: Neotropical Monogenoidea. 27. Two new species of Telethecium gen. $\mathrm{n}$. from the nasal cavities of central Amazonian fishes and a redescription of Kritskyia moraveci Kohn, 1990 (Dactylogyridae, Ancyrocephalinae). J. Helminthol. Soc. Wash. 63: 35-41.

PETRIE-HANSON L. 2001: First reported mortality and associated pathology attributed to Acolpenteron ureteroecetes in largemouth bass. J. Aquat. Anim. Health 13: 364-367.

ROGERS W.A. 1968: Pseudacolpenteron pavlovskyi Bychowsky and Gussev, 1955 (Monogenea), from North America, with notes on its taxonomic status. J. Parasitol. 54: 339 .

TAKEMOTO R.M., LIZAMA M.P., PAVANELLI G.C. 2002: A new species of Kritskyia (Dactylogyridae, Ancyrocephalinae) parasite of urinary bladder of Prochilodus lineatus (Prochilodontidae, Characiformes) from the Floodplain of the high Paraná River, Brazil. Mem. Inst. Oswaldo Cruz 97: 313-315.

VIOZZI G., GUTIÉRREZ P. 2001: Philureter trigoniopsis, a new genus and species (Dactylogyridae, Ancyrocephalinae) from the ureters and urinary bladder of Galaxias maculatus (Osmeriformes: Galaxiidae) in Patagonia (Argentina). J. Parasitol. 87: 392-394.

YAMAGUTI S. 1963: Systema Helminthum. Monogenea and Aspidocotylea. Vol. IV. Interscience Publishers, New York, 699 pp.

Accepted 8 January 2003 